\title{
ANTIRADICAL, ANTIBACTERIAL AND ANTIFUNGAL ACTIVITY OF HARPULLIA ARBOREA (BLANCO) RADLK. (SAPINDACEAE)
}

\author{
RAGHAVENDRA H. L. ${ }^{1}$, PRASHITH KEKUDA T. R. ${ }^{2}$, KARTHIK K. N. ${ }^{2}$, ANKITH G. N. ${ }^{2}$ \\ ${ }^{1}$ Department of Biochemistry, School of Medicine, Wollega University, P. O. Box: 395, Nekemte, Ethiopia, ${ }^{2}$ Department of Microbiology, S. \\ R. N. M. N. College of Applied Sciences, N. E. S. Campus, Balraj Urs Road, Shivamogga 577201, Karnataka, India \\ Email: p.kekuda@gmail.com \\ Received: 20 May 2017, Revised and Accepted: 22 Jul 2017
}

\begin{abstract}
Objective: The present study was conducted to investigate antiradical and antimicrobial potential of extract of Harpullia arborea (Blanco) Radlk. (Sapindaceae) leaves obtained by maceration process.

Methods: Antiradical activity of leaf extract was performed by DPPH and ABTS radical scavenging assays. Antibacterial activity of leaf extract was carried out by Agar well diffusion assay. Antifungal activity of leaf extract was carried out by Poisoned food technique.

Results: Leaf extract displayed concentration dependent scavenging of radicals with potent scavenging activity against $\mathrm{ABTS}_{\mathrm{B}}$ radicals (IC $\mathrm{50}_{5}$ value $4.26 \mu \mathrm{g} / \mathrm{ml}$ ) when compared to DPPH radicals ( $\mathrm{IC}_{50}$ value $27.26 \mu \mathrm{g} / \mathrm{ml}$ ). Extract exhibited inhibitory activity against all test bacteria. Marked and least activity was observed against Staphylococcus epidermidis and Escherichia coli respectively. Considerable reduction in the mycelial growth of test fungi was observed in poisoned plates. Curvularia sp. and Alternaria sp. were inhibited to highest and least extent respectively.
\end{abstract}

Conclusion: In suitable form, the plant can be used to treat oxidative damage, infectious diseases caused by pathogenic bacteria and to manage seed-borne fungi.

Keywords: Harpullia arborea, Maceration, Agar well diffusion, Poisoned food technique, DPPH, ABTS, IC 50

(C) 2017 The Authors. Published by Innovare Academic Sciences Pvt Ltd. This is an open access article under the CC BY license (http://creativecommons.org/licenses/by/4.0/] DOI: http://dx.doi.org/10.22159/ijcpr.2017v9i5.22133

\section{INTRODUCTION}

Harpullia arborea (Blanco) Radlk. Belonging to the family Sapindaceae is a medium sized evergreen tree native to Indo-Malayan. Leaves are compound, alternate, usually even, pinnate, up to $40 \mathrm{~cm}$ long. Flowers are greenish yellow, in axillary or subterminal panicles. Sepal 5, ovate and tomentose. Petals 5, ovate and clawed. Stamens 5-8, inserted on the disc. Ovary ovoid, 2-celled; ovules 2 in each cell, superposed. Fruit is a inflated, coriaceous, 2-lobed, 2-celled, loculicidally 2-valved dehiscent capsule, orange-red in color with 2 black seeds. In Karnataka, the plant is distributed in Chikamagalur, Shimoga, Hassan, Kodagu, Dakshina Kannada and Uttara Kannada [1, 2]. Various parts of $H$. arborea are used traditionally by the ethnic communities of Kerala, India as leech repellent, hair wash and to treat rheumatism [3]. In Tamil Nadu, the seeds of $H$. arborea were sold as an anthelmintic and a formulation Perali ennai containing the fruit of $H$. arborea, used as an appertizer and to cure digestive problems, was by herbal vendors [4]. In Maharashtra, the bark is traditionally used as leech repellent [5]. The seeds of $H$. arborea were shown to possess glycosides, steroids, saponins and resins [3]. Terpenoids, polyphenols, flavonoids and anthraquinones were detected in leaves while terpenoids and flavonoids were detected in stem [6]. A new norhopane triterpenoid, 3betaeicosanoyl-6beta-hydroxy-21alphaH-24-norhopan-4(23), 22(29)-diene, was isolated from leaves of $H$. arborea [7]. Solvent extracts of seeds were shown to possess antibacterial activity against Gram positive and Gram negative bacteria [3]. Leaves and stem extracts were shown to exhibit antimalarial activity against Plasmodium falciparum HRP2 [6]. The present study was carried out to investigate antiradical and antimicrobial activity of leaf of H. arborea.

\section{MATERIALS AND METHODS}

\section{Collection and identification of plant material}

The plant was collected near Shiralakoppa, Shivamogga district, Karnataka during February 2017 and identified by Dr. Vinayaka K. S, Assistant Professor, Department of Botany, KFGC, Shikaripura.

\section{Extraction}

The leaves were separated, washed using clean water, dried under shade and powdered. $10 \mathrm{~g}$ of powdered leaf material was subjected to maceration process using methanol $(100 \mathrm{ml})$ in a stoppered container. The powder was left in methanol for $48 \mathrm{~h}$ during which the container was stirred occasionally. The content was filtered through 4-fold muslin cloth followed by Whatman filter paper (No. $1)$. The filtrate was evaporated to dryness. The crude leaf extract obtained was stored in refrigerator [8].

\section{Antibacterial activity of $H$. arborea}

Agar well diffusion method was employed to investigate antibacterial activity of leaf extract against 7 bacteria (Gram positive bacteria-Staphylococcus aureus NCIM 5345, Staphylococcus epidermidis NCIM 2493, Bacillus subtilis NCIM 2063 and Bacillus cereus NCIM 2016; Gram negative bacteria-Escherichia coli NCIM 2065, Pseudomonas aeruginosa NCIM 2200 and Salmonella typhimurium NCIM 2501). The $24 \mathrm{~h}$ old Nutrient broth cultures of test bacteria were swab inoculated on sterile Nutrient agar plates and wells of $8 \mathrm{~mm}$ were created in the plates with the help of sterile cork-borer. The wells were labeled and filled with leaf extract (20 $\mathrm{mg} / \mathrm{ml}$ of Dimethyl sulfoxide [DMSO]), reference antibiotic (Chloramphenicol, $1 \mathrm{mg} / \mathrm{ml}$ of sterile distilled water) and DMSO. The plates were incubated in upright position at $37^{\circ} \mathrm{C}$ for $24 \mathrm{~h}$ and the zones of inhibition were measured $[8,9]$.

\section{Antifungal activity of $\boldsymbol{H}$. arborea}

In order to evaluate the antifungal potential of leaf extract against three seed-borne fungi namely Alternaria sp., Fusarium sp. and Curvularia sp., we performed Poisoned food technique. Control (without extract) and poisoned Potato dextrose agar (1 mg extract/ml of medium) plates were inoculated with the well sporulated cultures of test fungi followed by incubating the plates in upright position for $5 \mathrm{~d}$ at room temperature. The diameter of fungal colonies was measured and extent of mycelial growth inhibition by extract was calculated using the formula: 
Mycelial growth inhibition (\%) $=(\mathrm{C}-\mathrm{T} / \mathrm{C}) \times 100$, where ' $\mathrm{C}$ ' refers to colony diameter of test fungi on control plates and ' $\mathrm{T}$ ' refers to colony diameter of test fungi in poisoned plates $[8,9]$.

\section{DPPH radical scavenging activity of $H$. arborea}

Various concentrations of leaf extract and ascorbic acid in $1 \mathrm{ml}$ of methanol were mixed with $3 \mathrm{ml}$ of DPPH radical solution $(0.004 \%$ in methanol) in clean and dry tubes. The tubes were incubated for 30 min at room temperature in dark. The absorbance was read at $520 \mathrm{~nm}$ in a spectrophotometer. Radical scavenging potential of each concentration of leaf extract and ascorbic acid was determined using the formula:

Scavenging of DPPH radicals (\%) = (Ac-At/Ac) $\times 100$, where Ac and At represents the absorbance of DPPH control $(1 \mathrm{ml}$ methanol+3 $\mathrm{ml}$ DPPH radical solution) and absorbance of DPPH in presence of extract/ascorbic acid $[8,10]$.

\section{ABTS radical scavenging activity of $H$. arborea}

Various concentrations of leaf extract and ascorbic acid in $1 \mathrm{ml}$ of methanol were mixed with $3 \mathrm{ml}$ of ABTS radical solution (generated previously by mixing $7 \mathrm{mmol}$ ABTS stock and $2.45 \mathrm{mmol}$ potassium persulfate) in clean and dry tubes. The tubes were incubated for 30 min at room temperature in dark. The absorbance was read at 730 $\mathrm{nm}$ in a spectrophotometer. Radical scavenging potential of each concentration of leaf extract and ascorbic acid was determined using the formula:

Scavenging of ABTS radicals (\%) $=($ Ac-At $/ A c) \times 100$, where Ac and At represents the absorbance of ABTS control $(1 \mathrm{ml}$ methanol+3 ml DPPH radical solution) and absorbance of ABTS in presence of extract/ascorbic acid $[8,10]$.

\section{RESULTS AND DISCUSSION}

\section{Antibacterial activity of $H$. arborea}

Since discovery, antibiotics are considered as life-saving drugs as the use of antibiotics has saved millions of death due to infectious agents such as bacteria and fungi. However, the overuse and abuse of antibiotics results in the development of resistance in pathogenic microorganisms against the antibiotics. The resistant pathogens are of serious concern in both community and hospital settings as they are not susceptible to antibiotics and thereby cause marked morbidity and mortality. Plants have been considered as an excellent source of antimicrobials. Worldwide, many plants are used in the therapy of several diseases. Extracts and purified compounds from plants have shown to inhibit a wide range of pathogenic bacteria including antibiotic resistant strains $[8,9,11-14]$. Table 1 shows the result of antibacterial potential of leaf extract of $H$. arborea. All bacteria were susceptible to leaf extract but to a varied extent. Gram positive bacteria displayed high susceptibility to leaf extract when compared to Gram negative bacteria. S. epidermidis and $B$. cereus were susceptible to highest and least extent respectively among Gram positive bacteria. Among Gram negative bacteria, $P$. aeruginosa and $E$. coli were inhibited to highest and least extent respectively. Reference antibiotic caused high inhibition of test bacteria when compared to leaf extract. There was no inhibition caused by DMSO. In a study, the seed extract of $H$. arborea was shown to exhibit antibacterial activity in disk diffusion method [3] In the study of Chung et al. [15], only S. aureus was sensitive to bark extract while other bacteria and $C$. albicans were not inhibited by bark as well as leaf extract of $H$. arborea. Khan et al. [16] reported antibacterial effect of various parts of $H$. ramiflora. Ethyl acetate fraction of flower exhibited highest activity. Solvent fractions such as dichloromethane, ethyl acetate and butanol of methanol extract of $H$. petiolaris leaves, stem and root barks and heartwoods exhibited antibacterial activity [17]. Two new benzeneacetic acid derivatives viz. Harpulliaside A and B, isolated from $H$. pendula, were shown to exhibit antibacterial activity with prominent activity against Gram positive bacteria [18].

\section{Antifungal activity of $\boldsymbol{H}$. arborea}

Seed is an important input for production of majority of food crops. The use of good quality and disease free seeds results in desired germination and emergence of plants. Seeds often act as passive carriers of several fungi such as species of Aspergillus, Fusarium, Helminthosporium, Curvularia, Alternaria, Epicoccum, Mucor, Rhizopus, Cercospora, Pyricularia and Rhizoctonia and these fungi reduces seed viability, nutrients and cause diseases in seedlings and other stages of growth and result in yield losses. Management of seed-borne fungi is usually done with the use of synthetic chemicals. Interest in plants with antifungal activity against fungi from plant origin is intensified due to several drawbacks, such as high cost, environmental pollution and toxic effects on humans and other organisms, that are associated with the use of synthetic fungicides. Plant based agents are biodegradable, non-toxic and cheaper.

Many studies have shown the potential of botanicals to inhibit a range of seed-borne fungi [19-26]. In the present study, we evaluated the antifungal potential of leaf extract of $H$. arborea by Poisoned food technique. The result of antifungal potential of $H$. arborea is shown in table 2. All fungi were susceptible to extract as considerable reduction in the mycelial growth was observed in plates poisoned with leaf extract. The extract was found to inhibit the mycelial growth of all test fungi to $>40 \%$. Inhibition of Curvularia sp. was highest (55.5\%) followed by Fusarium sp. (53.5\%) and Alternaria sp. (42.3\%). In an earlier study, the seed extract of $H$. cupanioides exhibited strong antifungal activity against phytopathogenic fungi viz. Rhizoctonia solani, Curvularia lunata, Colletotrichum musae and Alternaria alternata [27].

Table 1: Antibacterial activity of leaf extract of $\boldsymbol{H}$. arborea

\begin{tabular}{llll}
\hline Test bacteria & Zone of inhibition in cm & & Antibiotic \\
\cline { 2 - 4 } & Leaf extract & 3.2 & 00.00 \\
\hline S. aureus & 1.7 & 3.4 & 00.00 \\
S. epidermidis & 2.0 & 3.5 & 00.00 \\
B. subtilis & 1.8 & 3.4 & 00.00 \\
B. cereus & 1.6 & 2.9 & 00.00 \\
P. aeruginosa & 1.4 & 2.4 & 00.00 \\
E. coli & 1.1 & 2.8 & 00.00 \\
S. typhimurium & 1.3 & & \\
\hline
\end{tabular}

Table 2: Antifungal activity of leaf extract of $H$. arborea

\begin{tabular}{|c|c|c|}
\hline \multirow[t]{2}{*}{ Test fungi } & \multicolumn{2}{|c|}{ Colony diameter in $\mathrm{cm}$} \\
\hline & Control & H. arborea \\
\hline Curvularia sp. & 4.5 & 2.0 \\
\hline Alternaria sp. & 5.2 & 3.0 \\
\hline Fusarium sp. & 4.3 & 2.0 \\
\hline
\end{tabular}




\section{Antiradical activity of $\boldsymbol{H}$. arborea}

A free radical is any molecular species which contains an unpaired electron in an atomic orbital and the presence of this unpaired electron is responsible for sharing certain common properties by most radicals. These radicals are generated during normal metabolism and exposure to environmental factors such as pollution and radiation. The most important oxygen-containing free radicals that are implicated in many disease states (such as cancer, ageing, cardiovascular diseases and neurodegenerative diseases) are hydroxyl radical, superoxide anion radical and nitric oxide radical and peroxy nitrite radical. The free radicals are unstable, highly reactive and are known to damage biomolecules such as proteins, lipids and nucleic acids. Antioxidants are substances which can neutralize and decrease the deleterious effects caused by free radicals and other non-radical species. Interest in botanicals with antioxidant activity has been intensified due to suspected negative effects that are associated with the use of synthetic antioxidants. Plants are shown to be potent sources of natural antioxidants and many of the plant metabolites especially polyphenolic compounds are known to act as potent antioxidants [28-34].
The method of scavenging of DPPH radical (stable, organic, nitrogen centered free radical) is extensively used for determining the radical scavenging potential of various kinds of samples including plant extracts. The method is popular in being simple, rapid, and cheaper and the results obtained are reproducible. In this method, the substances (antioxidants) having the potential to donate proton causes decolorization of purple colored DPPH radical to yellow colored non-radical DPPHH [8, 9, 30, 35-38]. Fig. 1 shows the result of scavenging potential of leaf extract of $H$. arborea against DPPH radicals. The leaf extract was found to scavenge radical's dose dependently with an $\mathrm{IC}_{50}$ value of $27.26 \mu \mathrm{g} / \mathrm{ml}$. A scavenging of $>50 \%$ and higher was observed at extract concentration $50 \mu \mathrm{g} / \mathrm{ml}$ and higher. At $100 \mu \mathrm{g} / \mathrm{ml}$, a scavenging activity of $66.66 \%$ of radicals was observed. Ascorbic acid scavenged radicals more efficiently with an $\mathrm{IC}_{50}$ value $3.06 \mu \mathrm{g} / \mathrm{ml}$ when compared to leaf extract. In an earlier study, Moustafa et al. [39] observed DPPH radical scavenging potential of two Harpullia species viz. H. cupanioides and H. pendula. Although, leaf extract scavenged DPPH radicals to lesser extent when compared to ascorbic acid, it is evident that the leaf extract of $H$. arborea possess hydrogen donating potential and thereby it can act as a free radical scavenger.

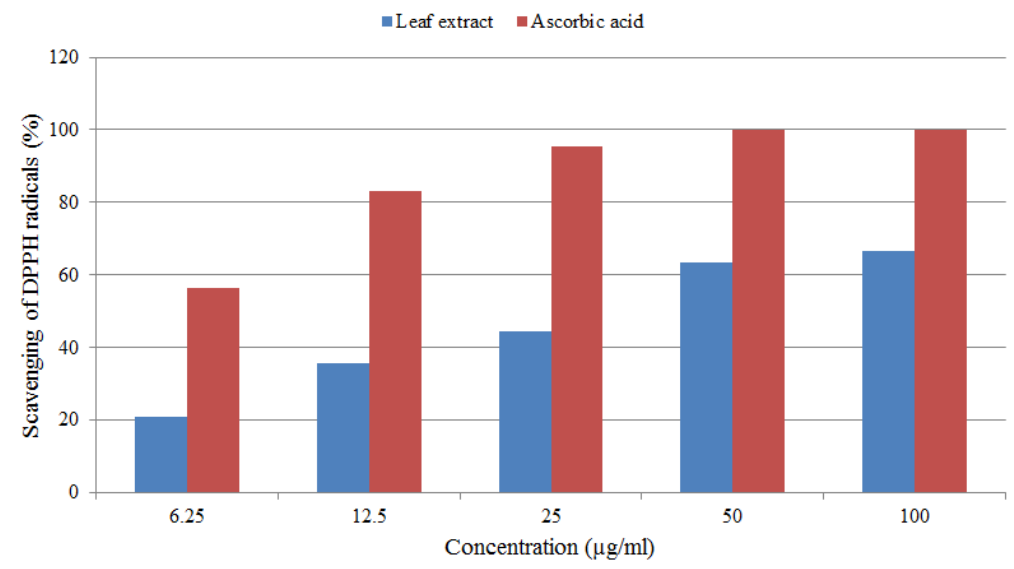

Fig. 1: Scavenging of DPPH radicals by leaf extract of $H$. arborea and ascorbic acid

Like DPPH assay, the assay involving scavenging of ABTS radicals is another simple, rapid and popular in vitro antiradical assay. In this assay, ABTS salt is oxidized to its radical cation which is intensely colored and the antiradical activity is measured as the ability of substances to decrease the color. In this assay, substances having electron donating potential converts blue-green colored ABTS radicals to colorless neutral form which is evidenced by suppression of its characteristic long wave absorption spectrum. ABTS radicals scavenging assay is widely used to evaluate antiradical activity of plants [8, 10,40-43]. The result of scavenging potential of leaf extract against ABTS radicals is shown in fig. 2 . The leaf extract was effective in scavenging ABTS radical's dose dependently with an $\mathrm{IC}_{50}$ value of $4.26 \mu \mathrm{g} / \mathrm{ml}$. A scavenging of $>50 \%$ and higher was observed at all extract concentrations. Ascorbic acid was found to scavenge ABTS radicals more efficiently with an $\mathrm{IC}_{50}$ value $2.48 \mu \mathrm{g} / \mathrm{ml}$ when compared to leaf extract. It is clear from the result that the leaf extract possess electron donating potential and hence, it can act as a free radical scavenger.

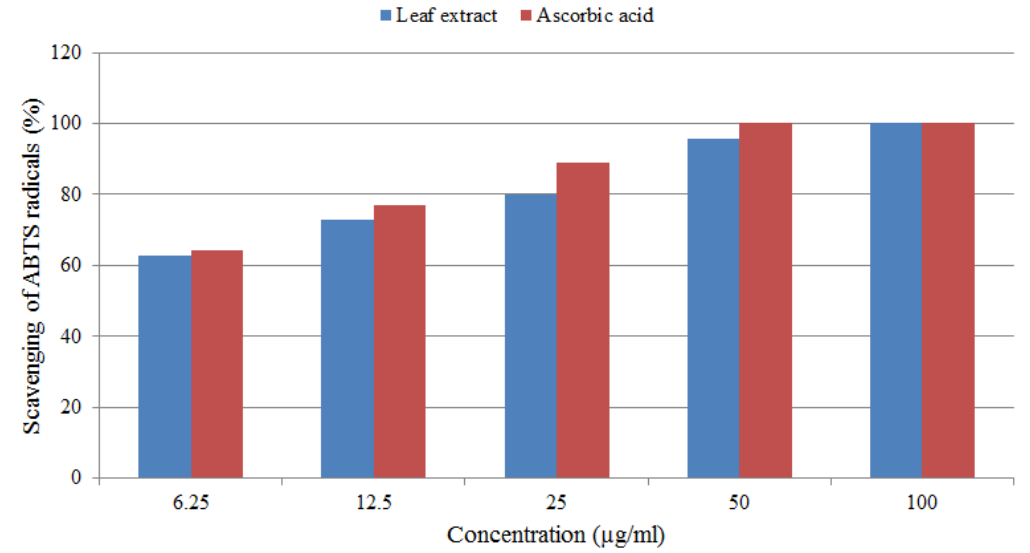

Fig. 2: Scavenging of ABTS radicals by leaf extract of $H$. arborea and ascorbic acid 


\section{CONCLUSION}

The leaf extract of $H$. arborea was shown to possess marked antimicrobial and antiradical potential. In suitable form, the plant can be used to treat infectious diseases and oxidative damage and manage seed-borne fungal diseases. Further studies on purification of active principles from the extract and determination of their potent biological roles are to be carried out.

\section{ACKNOWLEDGEMENT}

Authors are thankful to Head of the Department of Microbiology and Principal of S. R. N. M. N College of Applied Sciences for providing facilities to work. Authors express sincere thanks to N. E. S, Shivamogga for moral support. Authors also thank Dr. Vinayaka K. S for assisting in collection and identification of plant material.

\section{CONFLICT OF INTERESTS}

Declare none

\section{REFERENCES}

1. Singh B, Singh VN, Sinha BK, Phukan SJ, Borthukar SK. Harpullia arborea (Blanco) radlk.-a new record to Meghalaya. J NonTimber Forest Prod 2011;18:237-8.

2. Bhat GK. Flora of South Kanara. Akriti Prints, Mangalore, India; 2014.

3. Gowri SS, Vasantha K. Solvent based effectiveness of antibacterial and phytochemical derivatized from the seeds of Harpullia arborea (Blanco) Radlk. (Sapindaceae). J Appl Sci Environ Management 2009;13:99-101.

4. Karuppusamy S, Rajasekaran KM, Karmegam N. Evaluation of phytomedicines from street vendors in Tamil Nadu, South India. Indian J Traditional Knowledge 2002;1:26-39.

5. Sharma PP, Sawant RJ. Indigenous traditional practices for ecofriendly management of insect/pest in Maharashtra, India. Recent Res Sci Technol 2012;4:21-4.

6. Widyawaruyanti A, Devi AP, Fatria N, Tumewu L, Tantular IS, Hafid AF. In vitro antimalarial activity screening of several Indonesian plants using HRP2 assay. Int J Pharm Pharm Sci 2014;6:125-8.

7. Poovapatthanachart R, Thanakijcharoenpath W. A new norhopane from Harpullia arborea. Fitoterapia 2008;79:498500 .

8. Raghavendra HL, Kekuda PTR, Akarsh S, Ranjitha MC, Ashwini HS. Phytochemical analysis, antimicrobial and antioxidant activities of different parts of Pleocaulus sessilis (Nees) Bremek (Acanthaceae). Int J Green Pharm 2017;11:98-107.

9. Kekuda PTR, Rakesh KN, Dileep N, Junaid S, Pavithra GM, Gunaga SS, et al. Antimicrobial and antioxidant activity of Anaphalis lawii (Hook. f.) Gamble. Sci Technol Arts Res J 2012;1:8-16.

10. Rakesh KN, Junaid S, Dileep N, Vinayaka KS, Kekuda PTR, Raghavendra HL. Antibacterial and antioxidant activity of Fahrenheitia zeylanica (Thw.) Airy. Sci Technol Arts Res J 2013;2:27-33.

11. Cowan MM. Plant products as antimicrobial agents. Clin Microbiol Rev 1999;12:564-82.

12. Al Laham SA, Al Fadel FM. Antibacterial activity of various plants extracts against antibiotic-resistant Aeromonas hydrophila. Jundishapur J Microbiol 2014;7:e11370.

13. Fankam AG, Kuiate JR, Kuete V. Antibacterial and antibiotic resistance modifying activity of the extracts from allanblackia gabonensis, combretum molle and gladiolus quartinianus against gram-negative bacteria including multi-drug resistant phenotypes. BMC Complementary Altern Med 2015;15:206.

14. Tankeo SB, Damen F, Sandjo LP, Celik I, Tane P, Kuete V. Antibacterial activities of the methanol extracts, fractions and compounds from Harungana madagascariensis Lam. ex Poir. (Hypericaceae). J Ethnopharmacol 2016;190:100-5.

15. Chung PY, Chung LY, Ngeow YF, Goh SH, Imiyabir Z. Antimicrobial activities of Malaysian plant species. Pharm Biol 2004;42:292-300.

16. Khan MR, Kihara M, Omoloso AD. Antimicrobial activity of Harpullia ramiflora. Fitoterapia 2001;72:298-300.
17. Khan MR, Omoloso AD. Antibacterial, antifungal activity of Harpullia petiolaris. Fitoterapia 2002;73:331-5.

18. Abdelkader MSA, Rateb ME, Mohamed GA, Jaspars M. Harpulliasides A and B: two new benzeneacetic acid derivatives from Harpullia pendula. Phytochem Lett 2016;15:131-5.

19. Imolehin ED. Rice seedborne fungi and their effect on seed germination. Plant Disease 1983;67:1334-6.

20. Chandra M, Mahesh NM. Antifungal activity of medicinal plant extracts against seed-borne pathogenic fungi. Acta Biol Indica 2013;2:481-3.

21. Perello A, Gruhlke M, Slusarenko AJ. Effect of garlic extract on seed germination, seedling health, and vigour of pathogeninfested wheat. J Plant Protection Res 2013;53:317-23.

22. Sadhu KA. Seed-borne fungi and their effect on seed health of green gram. Biosci Discovery 2014;5:251-5.

23. Anjorin ST, Mohammed M. Effect of seed-borne fungi on germination and seedling vigour of watermelon (Citrullus lanatus thumb). Afr J Plant Sci 2014;8:232-6.

24. Pawar BT. Antifungal activity of some seed extracts against seed-borne pathogenic fungi. Int Arch Appl Sci Technol 2015;6:44-6.

25. Nagpurne VS, Patwari JM. Studies on antimicrobial activity of medicinal plants against seed-borne pathogenic fungi. Int Res J Biol Sci 2016;5:54-6.

26. Kekuda PTR, Raghavendra HL. Antifungal activity of Helichrysum buddleioides DC. against seed borne fungi. EC Microbiol 2017;6:54-9.

27. Bharathimatha C, Doraiswamy S, Velazhahan R. Inhibition of fungal plant pathogens by seed proteins of Harpullia cupanioides (Roxb.). Acta Phytopathol Entomol Hung 2002;37:75-82.

28. Pham Huy LA, He H, Pham Huy C. Free radicals, antioxidants in disease and health. Int J Biomed Sci 2008;4:89-96.

29. Lobo V, Patil A, Phatak A, Chandra N. Free radicals, antioxidants and functional foods: impact on human health. Pharmacogn Rev 2010;4:118-26

30. Pawar C, Surana S. Antioxidant properties of the methanol extract of the wood and pericarp of Caesalpinia decapetala. J Young Pharm 2010;2:45-9.

31. Sudharshan SJ, Valleesha NC, Chinmaya A, Kekuda PTR, Murthuza S, Rajeshwara AN. Radical scavenging activity, phenol and flavonoid content of selected traditionally used Indian medicinal plants. Asian J Exp Sci 2010;24:11-5.

32. Sivanandham V. Free radicals in health and diseases-a mini review. Pharmacologyonline 2011;1:1062-77.

33. Alok S, Jain SK, Verma A, Kumar M, Mahor A, Sabharwal M. Herbal antioxidant in clinical practice: a review. Asian Pacific ] Trop Biomed 2014;4:78-84.

34. Pisoschi AM, Pop A, Cimpeanu C, Predoi G. Antioxidant capacity determination in plants and plant-derived products: a review. Oxid Med Cell Longevity 2016. http://dx.doi.org/ $10.1155 / 2016 / 9130976$

35. Okawa M, Kinjo J, Nohara T, Ono M. DPPH (1,1-diphenyl-2picrylhydrazyl) radical scavenging activity of flavonoids obtained from some medicinal plants. Biol Pharm Bull 2001;24:1202-5.

36. Molyneux P. The use of the stable free radical diphenylpicrylhydrazyl (DPPH) for estimating antioxidant activity. Songklanakarin J Sci Technol 2004;26:211-9.

37. Kedare SB, Singh RP. Genesis and development of DPPH method of antioxidant assay. J Food Sci Technol 2011;48:412-22.

38. Kicel A, Wolbiś M. Phenolic content and DPPH radical scavenging activity of the flowers and leaves of Trifolium repens. Nat Prod Commun 2013;8:99-102.

39. Moustafa SMA, Menshawi BM, Wassel GM, Mahmoud K, Mounier MM. Screening of some wild and cultivated Egyptian plants for their free radical scavenging activity. Int J PharmTech Res 2014;6:1271-8.

40. Re R, Pellegrini N, Proteggente A, Pannala A, Yang M, RiceEvans C. Antioxidant activity applying an improved ABTS radical cation decolorization assay. Free Radical Biol Med 1999;26:1231-7. 
41. Prior RL, Wu X, Schaich K. Standardized methods for the determination of antioxidant capacity and phenolics in foods and dietary supplements. J Agric Food Chem 2005;53:4290-302.

42. Biskup I, Golonka I, Gamian A, Sroka Z. Antioxidant activity of selected phenols estimated by ABTS and FRAP methods. Postepy Hig Med Dosw 2013;67:958-63.

43. Shalaby EA, Shanab SMM. Comparison of DPPH and ABTS assays for determining antioxidant potential of water and methanol extracts of Spirulina platensis. Indian J Geo-Marine Sci 2013;42:556-64.

\section{How to cite this article}

- Raghavendra HL, Prashith Kekuda TR, Karthik KN, Ankith GN. Antiradical, antibacterial and antifungal activity of Harpullia arborea (blanco) radlk. (sapindaceae). Int J Curr Pharm Res 2017;9(5):32-36 